\title{
Marine invertebrate diversity in Aristotle's zoology
}

\author{
Eleni Voultsiadou ${ }^{1}$, Dimitris Vafidis ${ }^{2}$ \\ ${ }^{1}$ Department of Zoology, School of Biology, Aristotle University of Thessaloniki, GR - 54124 Thessaloniki, Greece, \\ elvoults@bio.auth.gr; ${ }^{2}$ Department of Ichthyology and Aquatic Environment, School of Agricultural Sciences, Uni- \\ versity of Thessaly, 38446 Nea Ionia, Magnesia, Greece,dvafidis@uth.gr
}

Key words: Animals in antiquity, Greece, Aegean Sea

\begin{abstract}
The aim of this paper is to bring to light Aristotle's knowledge of marine invertebrate diversity as this has been recorded in his works 25 centuries ago, and set it against current knowledge. The analysis of information derived from a thorough study of his zoological writings revealed 866 records related to animals currently classified as marine invertebrates. These records corresponded to 94 different animal names or descriptive phrases which were assigned to 85 current marine invertebrate taxa, mostly $(58 \%)$ at the species level. A detailed, annotated catalogue of all marine anhaima ( $a=$ without, haim $a=$ blood $)$ appearing in Aristotle's zoological works was constructed and several older confusions were clarified. Some of Aristotle's "genera" were found to be directly correlated to current invertebrate higher taxa. Almost the total of the marine anhaima were benthic invertebrates. The great philosopher had a remarkable, well-balanced scientific knowledge of the diversity of the various invertebrate groups, very similar to that acquired by modern marine biologists in the same area of study. The results of the present study should be considered as a necessary starting point for a further analysis of Aristotle's priceless contribution to the marine environment and its organisms.
\end{abstract}

\section{Contents}

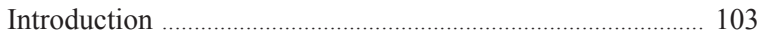

Material and methods ……………………………………......... 104

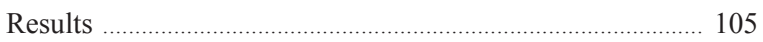

Malakia $(\mu \alpha \lambda \alpha \dot{\alpha} \kappa \iota)$ (having a soft body) ........................... 105

Malakostraka ( $\mu \alpha \lambda \alpha \kappa o ́ \sigma \tau \varrho \alpha \kappa \alpha)$ (having a soft shell) ..... 107

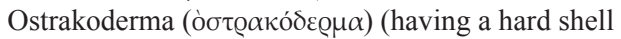

surrounding the body) ..................................................... 108

Other marine anhaima $(\ddot{\alpha} v \alpha \iota \mu \alpha)$ not classified in

the above major groups ……............................................ 112

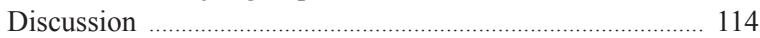

Aristotle's major genera and higher taxa ......................... 114

Classical animal names and their assignment to current taxa 115

Aristotle's scientific knowledge of marine

invertebrate diversity ........................................................ 115

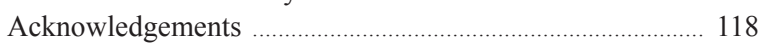

References …….................................................................. 118

\section{Introduction}

Aristotle was the one who created the idea of a general scientific investigation of living things. Moreover he created the science of biology and the philosophy of biology, while his animal studies profoundly influenced the origins of modern biology (Lennox, 2001a). His biological writings, constituting over $25 \%$ of the surviving Aristotelian corpus, have happily been the subject of an increasing amount of attention lately, since both philosophers and biologists believe that they might help in the understanding of other important issues of his philosophy (Gotthelf and Lennox, 1987) and they may introduce a new generation of biologists to the richness of Aristotle's biological observations and the questions that motivated them (Tipton, 2006).

On the basis of his zoological works, he has been considered as "the founder of zoology" (Pellegrin, 1982) and "the father of zoological classification" (Mayr and Ashlock, 1991). He was the first who gathered information on species of animals, examined their similarities and differences, and attempted to classify them into groups although, as pointed out by various authors (Peck, 1965; Pellegrin, 1982; Mayr and Ashlock, 1991), his aim was not to present an orderly, fully consistent classification of the animal kingdom. This did not prevent Darwin from considering him as "one of the greatest ... observers that ever lived", and also as the ancient equivalent of the great systematist Linnaeus by saying, in his famous 1882 letter to W. Ogle, that "Linnaeus and Cuvier have been my two gods ... but they are mere school-boys to old Aristotle" (Gotthelf, 1999). His contribution to the classification of animals has been a subject of analysis and evaluation by philosophers such as Lloyd (1961) and Pellegrin (1982). Biologists, on the other hand, have greatly appreciated his contribution to various biological disciplines (Moore, 1987; Kiortsis, 1989; Mayr and Ashlock, 1991; Sofianidou, 2004).

Around 500 animals are examined in his zoological 
works. During his stay for about 2 years in Lesbos Island, Aristotle devoted a considerable part of his biological research to marine animals (Thompson, 1913; Lee 1948; Solmsen 1978). Information on the morphology, anatomy, reproduction, development, habitat, diet and behavior of marine invertebrates, fishes, cetaceans and pinnipeds is given in his zoological works and their first classification scheme is presented. Thus, he is fairly considered to be the first marine biologist (Castro and Huber, 1997). Nevertheless, these data have not been paid special attention by modern researchers, with the exception of Aristotle's malakia, the current cephalopods (see Scharfenberg, 2001). A few attempts to examine Aristotle's marine animals are included in more general works by non specialists (Thompson, 1947; Louis, 1973) and can serve as a basis for a thorough analysis. However, many descriptions of marine animals have not been conclusively identified, and there is scope for new and interesting discoveries in his work (Balme, 1970).

We think that Aristotle's contribution to the knowledge of marine life needs to be studied in detail and evaluated under the scope of modern marine biology. As Voultsiadou and Tatolas (2005) pointed out, useful zoological information can be derived from the study of classical texts; this, among other benefits, may help historical zoogeographers as a supplement to paleontology, archaeology, and art in the reconstruction of faunas of older epochs. The aim of the present paper is to bring to light Aristotle's knowledge of marine invertebrate diversity as this has been presented in his zoological works 25 centuries ago and set it against current knowledge. This was achieved mainly by presenting a detailed, annotated catalogue of all animals appearing in Aristotle's zoological works, recognized nowadays as marine invertebrates.

\section{Materials and methods}

The first step was to go carefully through Aristotle's zoological works searching for records of what we call today "marine invertebrates". The works studied, and their scope as defined by Aristotle himself, are the following:

I. History of animals (HA) aiming "to determine first of all the differences that exist [among animals] and the actual facts in the case of all of them" because "having done this, we must attempt to discover the causes" (HA 491a12). Here, a description of the observed diversity in animal structure, function and behavior is given.
II. Parts of animals (PA), the task here being "to consider what are the causes through which each animal is as I described it" [in Histories of Animals] (PA 646a10). Structure is herein examined in relation to function, and a long discussion is given on the scientific method and the principles of zoology.

III. Movement of animals (MA), examining "the common cause of animal movement of whatever kind and how the soul moves the body and what is the origin of movement in an animal" (MA 698a4). The general mechanism of movement in animals is examined mostly theoretically.

IV. Progression of animals (IA) discussing "the parts which are useful to animals for their movement... why each part is of the nature which it is and why they possess them ... the differences in the various parts of one and the same animals and in those of animals of different species compared with one another" (IA 700b11).

V. Generation of animals (GA) aiming "to describe those [parts] which subserve animals for the purpose of generation" and to deal with its "motive cause and to explain what it is" GA (715a12). This is a study on reproduction, embryology and development of animal characteristics.

The publications of LOEB Classical Library, Harvard University (Peck, 1942, 1961, 1970; Forster, 1961; Balme, 1991) were used for the study of the classical texts and their English translations for the quotations reported in the paper. Additionally, other editions of classical texts (Balme 2002) and translations of Aristotle's zoological works (Lennox, 2001b) were consulted. The results of the detailed examination of all the above texts were crosschecked using the searching machine offered by the Online Thesaurus Linguae Graecae database (TLG E, Edition 2000). TLG and the Liddel and Scott Dictionary of Greek language were used for the estimation of Aristotle's contribution to the nomenclature of modern zoology.

All animal names were carefully examined in order to be correlated to current marine invertebrate taxa. The identification of animals encountered in the texts and their correlation to recent marine invertebrate taxa was not an easy task, since Aristotle's descriptions were very detailed and accurate in some cases, but fragmentary in others. Classical Greek names often proved very helpful, since they embodied information on their morphology or life history; this information was made available thanks to the continuity of Greek language. On the contrary, Latin scientific names inspired by Aristotle's animal names were sometimes confusing, 
such as holothourion, balanos and nautilos, which were given to animals other than the original, possibly due to misunderstanding of Aristotle's descriptions. Moreover, marine invertebrates are a very diverse group of animals including species not very well known, as for example other groups like mammals or birds. Their knowledge requires expertise in a number of totally different taxa belonging to almost all the known animal phyla. So, the personal experience of the authors on the Mediterranean, and more specifically Aegean, diversity of marine invertebrates such as decapod crustaceans (Koukouras et al., 1992), anthozoans (Vafidis et al., 1994; 1997), ascidians (Koukouras et al., 1995), gastropods (Koutsoubas et al., 1997), sponges (Voultsiadou-Koukoura et al., 1987; Voultsiadou, 2005), was critical, and their database of all literature on Aegean invertebrate fauna proved very useful. The construction of a complete catalogue was made possible thanks to the conclusive identification of several descriptions for the first time and the clarification of various misidentifications and confusing points found in previous works, such as in the cases of sponges, anthozoans, crinoids, polychaetes, and echiurans. A series of zoological books (Ruppert et al., 2004), general zoological publications on Mediterranean invertebrates (Riedl 1963; Fischer et al., 1987; Weinberg 1993; Hayward and Ryland 1996), as well as more specialized ones (Ingle 1996; Delamote and Vardala, 1994), were really helpful in the evaluation of the collected information. For details on the identification procedure see Voultsiadou and Tatolas (2005).

\section{Results}

Overall 866 records corresponding to animals currently classified as marine invertebrates were encountered in the studied texts. These records were unequally distributed in four of the studied works by Aristotle as follows: the majority -582 records- was found in History of animals, 195 in Parts of animals, 74 in the Generation of animals and 15 in Progression of animals. No specific animal records occurred in Movement of animals. All these records corresponded to 94 different animal names or descriptive phrases. Notice that Aristotle often needed to report animals that were not given a name up to his age. In such cases, he gave a short description of the animal's characteristic features or life history, e.g.

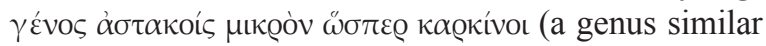

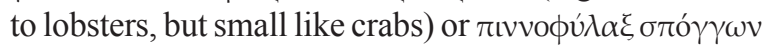
(pinna-guard of sponges), which is what we report here as "descriptive phrases".
A detailed identification and assignment of all marine anhaima $(a=$ without, haim $a=$ blood $)$ to recent marine invertebrate taxa, as these are classified in the groups defined by Aristotle himself, is given below. As is well known, Aristotle divided animals into anhaima ( $(\hat{\alpha} v \alpha \mu \alpha \alpha)$ meaning bloodless and enhaima (čv $\alpha \iota \mu \alpha)$ meaning blooded, these two groups corresponding to what we call today invertebrates and vertebrates. Further on, he recognized four groups of bloodless animals: apart from entoma (insects) that do not fall into the scope of our study, these were ostrakoderma (having a hard shell surrounding the body), malakia (having a soft body), and malakostraka (having a soft shell) (Fig. 1).

The necessary documentation for the identifications were quoted from the classical texts and comments on etymology and other animal characteristics, helpful for identification, are also cited. The extent of documentation depends on how well known or common an animal is. Therefore, we did not consider it necessary to quote and comment on the identity of animals such as the common edible sea urchin, which is frequently recorded and thoroughly described in the texts. On the other hand, the identification of animals not very common or not easily recognizable was supported by detailed evidence. Animal names were transliterated in Latin for the convenience of the reader. Transliteration was made according to Brown (1979) and Lennox (2001b). All the records of each animal name in the examined texts are given. Superscript numbers in each name or descriptive phrase correspond to the taxa names listed in Table 2. Each number corresponds to one of Aristotle's animal names.

\section{Malakia ( $\mu \alpha \lambda \alpha ́ \kappa \iota \alpha)$ (having a soft body)}

Malakia $^{1}(\mu \alpha \lambda \dot{\alpha} \kappa \iota \alpha)$ : a general name for Cephalopoda Mollusca. A definition (HA 523b2) and a full description (HA 523b22) of the group are given: "the fleshy part is exterior and the hard part (if any) interior". Their body "consists of the feet, the head which is continuous with the feet, the sac which contains the internal parts and a skin around it" (HA 523b35). It "includes cuttlefish and the squids, which have hard parts inside and the octopuses, which has no hard part at all" (HA 524b22).

HA 487b16, 489b34, 490a23, b12, 494b27, 523b2, b21, b26, 524a21, b8, b14, 525a18, a29, 531a1, b18, 534b14, b15, 535b13, 537a1, b4, b25, 539a11, 541b1, 544a1, 549a19, b29, 567b8, b10, $589 b 20,590 b 20, b 33,591 b 5, b 10,606 a 10,607 b 6,621 b 28,622 a 32$, b1, PA 644b10, 654a10, a13, a14, 678a27, b7, b25, 679a4, b6, b32, 681b11, b17, 684b6, b17, b19, b34, 685a4, a9, a10, a12, a27, IA 706b1, GA 715b1, 717a4, 720b5, 721a32, 727b2, 732b6, 733a22, a29, 733b10, 741b33, 755b32, 757b31, 758a15, a20, $761 b 5$. 


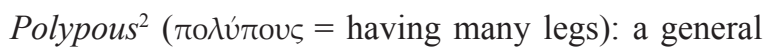
name for the Octopoda Cephalopoda, used also for the common octopus which is the largest, edible kind. Three categories are recognized: the first includes the largest edible octopus and some smaller not edible ones, the second includes the heledōne with "one row of suckers", and the third those "living inside a shell".

HA 490a1, 523b29, 524a3, a20, a21, a28, b28, 525a3, a6, $a 13, a 21,521 b 2, b 29,532 a 2,534 a 25, b 25, b 27,541 b 1, b 4$, 544a6, 549b31, 550a3, b1, b4, b15, 557a23, 590b14, b18, 591a1, 607b7, 621b17, b30, 622a3, a14, a15, a23, a24, a25, a29, a32, b5, PA 642b19, 644b25, 652b25, 654a22, 661a15, 678b28, $679 a 7, a 12, a 22, a 37,685 a 5, a 14, a 22, a 24, b 2, b 12, b 20, b 24$, GA 720b33, 758a8.

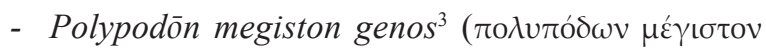

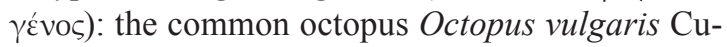
vier, 1797. It is discriminated from other smaller octopuses for its greater size, its habit to approach the water level and because it is edible ( $H A$ 525a14).

HA $525 a 14$.

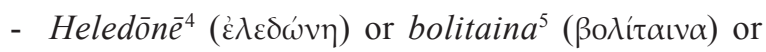

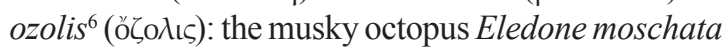
(Lamarck, 1798). It is discriminated from other octopuses by its longer arms each "bearing one single row of suckers" (HA 525a19). The name ozolis (óc $\omega=$ to stink) indicates its characteristic unpleasant smell. Scharfenberg's (2001) opinion that heledōne and volitaena or ozolis are two different species does not seem to be valid. If such was the case Aristotle

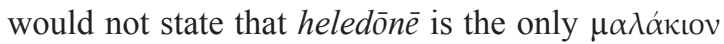
with a single row of suckers.

Heledōnē HA 525a17, volitaina HA 525a19, a26, 621b17, ozolis HA 525a19.

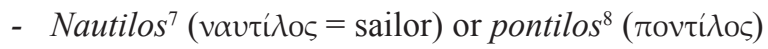
or óon polypodos ${ }^{9}(\hat{\omega}$ òv roגúrodos $=$ the egg of the polypous): the paper nautilus Argonauta argo Linnaeus, 1758. Although the name has been given to the recent genus Nautilus, Aristotle's description indicates the paper nautilus: its shell is described as "a single, deep scallop valve not joining with another" (HA 525a21). The way it moves up and down in the water is described (HA 622b1-19).

Nautilos HA 525a21, 622b5, pontilos HA 525a21, ōon polypodos HA 525a21.

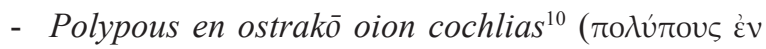

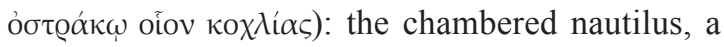
species of the genus Nautilus spp. It is briefly re- ported as "living inside a shell like a snail, sometimes protruding its tentacles" (HA 525a26). It is obvious that Aristotle had never seen a chambered nautilus; otherwise he would have been impressed by its appearance. It seems that he had rather been informed about its existence by somebody else, possibly someone accompanying Alexander the Great in his expeditions in the vicinity of the Indian Ocean, where the distribution of Nautilus species extends. Thompson (1947) suggested that Aristotle had in mind the species Janthina janthina (Linnaeus, 1758) and he must have mistaken for tentacles, the masses of eggs released by this floating species. Although J. janthina is common in the Aegean, it is very small in size and it could not be mistaken for an octopus.

HA $525 a 26$.

Sépia $^{11}(\sigma \eta \pi i \alpha)$ and sēpidion ${ }^{12}(\sigma \eta \pi i \delta$ เov = the young individual): the cuttlefish Sepia officinalis Linnaeus, 1758, described as "having the sepion ( $\sigma$ ri $\pi$ เov), a strong and broad internal hard part" (HA 524b25), and "the largest ink sac among all malakia" (HA 524b16). The use of ink discharge when the animal is in danger is mentioned (HA 621b29).

Sepia HA 489a33, b35, 490b13, 523b5, b29, 524a25, a27, b16, b17, b22, 525a6, 527a23, 529a4, 534b5, 541b1, b12, 544a2, $549 b 9, b 2, b 3, b 6, b 13, b 14, b 19,567 b 8, b 10,590 b 33,607 b 7$, 608b17, 621b29, b33, 622a11, a32, PA 654a20, 661a14, 678b28, 679a5, a9, a15, a20, 685a14, a23, b1, b20, GA 757b32, 758a6, a21, sepidion (young sepia) HA 550a10, a16, a19, a22, a26, a29, $a 31, b 16$.

Teuthos $^{13}$ ( $\left.\tau \varepsilon \tilde{v} \theta 0 \varsigma\right)$ : the sagittal squid Todarodes sagittatus (Lamarck, 1798). This common Mediterranean species is recognized by several characteristics given

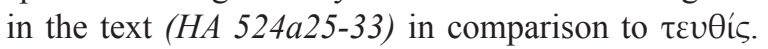
So, it is "bigger in size, has its sharp part (fin) broader, and its encircling fin goes all around the sac", possibly meaning that the two tentacles are long, almost surrounding the body when extended.

HA 490b13, 523b30, 524a25, a30, 550b14, $610 b 6$.

Teuthis $^{14}$ ( $\tau \varepsilon v \theta i(\varsigma)$ : the long finned squid Loligo vulgaris Lamarck, 1798. It is discriminated from teuthos by all the above mentioned characteristics and the fact that the "fin" observed in the former "is here absent" (HA 524a33).

HA 489b35, 490b13, 523b29, 524a25, a30, a32, a33, b22, b26, 541b1, b12, 550b12, b16, b17, 590b33, 607b7, 621b30, PA 654a21, 678b30, 679a7, a14, a22, 685a14, a24, b2, b19, GA $758 a 6$. 


\section{Malakostraka ( $\mu \alpha \lambda \alpha \kappa o ́ \sigma \tau \varrho \alpha \kappa \alpha)$ (having a soft shell)}

Malakostraka ${ }^{15}(\mu \alpha \lambda \alpha \kappa o ́ \sigma \tau \varrho \alpha \kappa \alpha)$ : a general name for Malacostraca (mostly Decapoda). It is one of the three $\gamma \varepsilon ́ v \eta$ (genera) of anhaima including animals having "their soft fleshy part inside and their hard part outside" (HA 523b5). The latter "can not be broken by a clean crack, it has to be crushed. It includes lobsters and crabs" (HA 490b11). They include four "major genera"

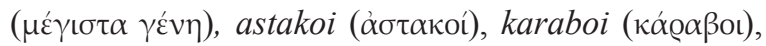

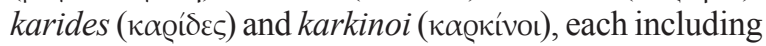
several species (PA 683b26).

HA 490b11, 523b5, 525a30, 527b34, 528a3, 529b21, 531b18, 534b14, b16, 535b14, 537a1, b5, b26, 539a10, 541b19, 549a14, 550a32, 589b20, 590b10, b32, 599b28, 601a17, 607b3, b5, PA 654a1, 661a13, 678a27, b10, b24, 679a31,b7, b31, 681b12, b20, 683b25, 684b17, b18, b31, 685b26, GA 715b1, 717a3, 720b5, $b 9, b 26,727 b 2,732 b 6,733 a 20, a 29, b 10,743 b 10,755 b 33$, $757 b 32,761 b 5,748 b 16$.

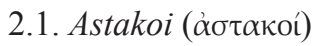

Astakos $^{16}$ ( $\left.\dot{\alpha} \sigma \tau \alpha \kappa o ́ \varsigma\right):$ the common lobster Homarus gammarus (Linnaeus, 1758). A detailed description and comparison of astakos with karabos is given (HA 526a11-b33), fully discriminating the two species. It is reported that "astakos has longer and more slender antennas, longer and more acute rostrum, smooth and not spiny carapace, as well as massive and unequal pincers".

HA 490b12, 525a32, b11, 526a11, 530a28, 541b20, b25, 549b14, b16, 601a10, PA 683b27, $684 a 32$.

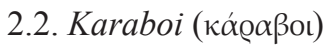

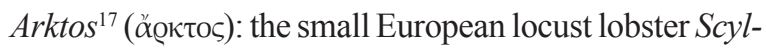
larus arctus (Linnaeus, 1758), compared with karabos for its spawning season (HA 549b23). The name ăoкто ( $=$ a bear) indicates the shape of the second antennae which on dorsal view resembles the footprint of a bear.

HA $549 b 23$.

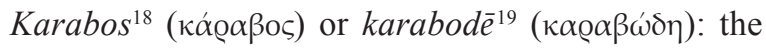
spiny lobster Palinurus elephas (Fabricius, 1787). A detailed description is given (HA 526a11-b33) and a comparison with the common lobster (see astakos).

Karabos HA 487b16, 489a33, 490a2, b11, 525b15, b21, b27, $b 33,526 a 15, a 31, a 32, b 2, b 4, b 5, b 13, b 20, b 21, b 23, b 25, b 26$, 527a1, a9, a11, a14, a16, a28, 529b22, 534b26, 537a1, 541b19, $549 a 14, b 9, b 13, b 17, b 23, b 27, b 28,590 b 12, b 14, b 16, b 16, b 20$, 601a10, a16, b17, PA 661a13, 679a31, a36, 683b27, 684a1, a16, a26, IA 713b29, b30, GA 757b33, karabodè HA 607b4, PA 683b31, GA 758a12, al6.

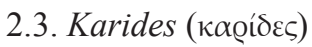

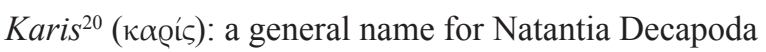
and Stomatopoda including shrimps, prawns and mantis shrimps (HA 525b1). The following kinds are distinguished.

HA 525a33, $a 34, b 1, b 17, b 27, b 32,526 b 27,527 a 9, a 20$, 541b20, b25, 547a6, 549b12, 591b14, PA 683b27, 684a14.

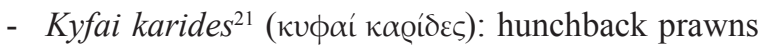
of the family Penaeidae. The description given (HA 525b17-30) corresponds to the typical prawns of this family such as the edible, common in the Aegean species Melicertus kerathurus (Forskal, 1775). Besides the "hunched back", the "five pairs of slender thoracic legs towards the head in opposition to the abdominal legs which have broad ends and the acute, spine bearing tail (telson)" are pointed out.

HA 525b1, b17, b28, 549b12.

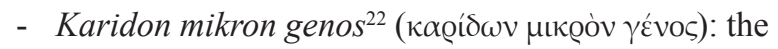
small kind (HA 525b2), a species of Natantia Decapoda. It could be any group of small sized shrimps, since no description is given.

HA $525 b 2$.

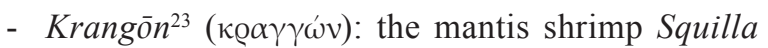
mantis (Linnaeus, 1758). The body structure of Stomatopoda is described in detail (HA 525b22-30); four plus three pairs of legs on the anterior part and a broad spiny tail (telson and two biramous uropods).

HA 525b2, b21, b29.

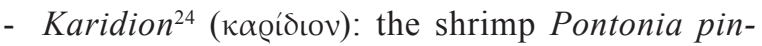
nophylax (Otto, 1821). The information given (HA 547b17) on the symbiotic relationship of this shrimp with the fan mussel (Pinna) indicates this species. Besides this specific meaning, the term karidion was used for a small karis.

HA $547 b 17$.

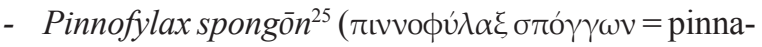
guard of sponges): shrimps of the family Alpheidae. They are "similar to those guarding the fan mussel, but growing in sponge canals" (HA 548a28). Common species of this family living inside Aegean sponges and similar to those of the genus Pontonia are Synalpheus gambarelloides (Nardo, 1847), Alpheus dentipes Guerin, 1832 and Typton spongicola Costa, 1844.

HA $548 a 28$. 


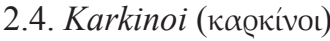

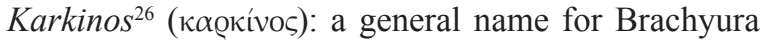
Decapoda. They are distinguished from lobsters and prawns by having a "rounded body" and by the "absence of a tail" (HA 525b31). They are considered as a "variable group including numerous species" (HA 525b5).

HA 525b5, b10, b16, b31, 526a10, a20, a28, 527a10, b4, $541 b 25, b 28,547 b 26,549 b 27,590 b 25,601 a 16, a 20$, PA 654a2, 679a32, 683b28, 684a2, a4, a8, a11, a15, a23, a26, 686a1, 691b16, b20, IA 712b13, b20, 713b11, 714b17.

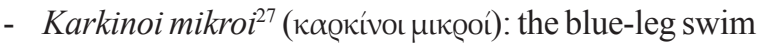
crab Polybius (Liocarcinus) depurator (Linnaeus, 1758). They are described as "little tiny crabs having their hindmost walking legs flattened like fins or oars, to make them useful for swimming, usually found among the catch with small fish" (PA 684a11). PA 684a11.

- Hippos ${ }^{28}$ (iтros = horse): the ghost crab Ocypode cursor ( $=$ O. hippeus) (Linnaeus, 1758) which is said to live in Phoenicia running fast on the beach ( $H A$ $525 b 7)$. It is a common species on the eastern coasts of the Levantine basin.

HA $525 b 7$.

- $\operatorname{Maia}^{29}(\mu \alpha i \tilde{\alpha} \alpha=$ midwife): the spiny spider crab Maja squinado (Herbst, 1788). The information given for this crab is that it is "the biggest among all crabs" (HA 525b4), "it lives in the deep and moves little about" (PA 684a8), "has a very hard shell" (HA 601a19) and "owe its safety to it, having for this reason thin feet, considerably less effective for locomotion" (PA 684a10). Moreover, it is said to "have its eyes in the middle and close together", in contrast to most other crabs "in which eyes are placed a long way apart from each other" (HA 527b7). M. squina$d o$ has all the above characteristics.

HA 525b4, b14, 601a19, PA 684a8, a10.

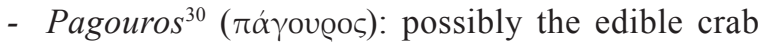
Cancer pagurus Linnaeus, 1778, according to older identifications (see Thompson 1947). No description exists but it is said to be "one of the biggest crabs in size" (HA 525b5).

HA $525 b 5$.

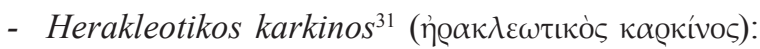
the shamefaced crab Calappa granulata (Linnaeus, 1758). It is described as "being in size next to maia" (HA 525b5), having also "a hard shell" for protection
(HA 601a19), its eyes "in the middle and close together" (HA 527b12), and "short legs not effective for locomotion" (PA 684a10).

HA 525b5, 527b12, 684a8, a10.

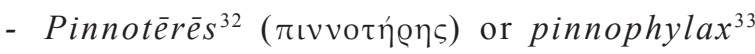

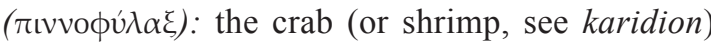
"guarding the fan mussel" (HA 547b16). It may "exist inside" other bivalves such as "the scallops and the oysters" (HA 547b28). Their "white color" indicates the species Pinnotheres pisum (Linnaeus, 1758).

HA 547b16, b28.

\subsection{Unclassified malakostraka}

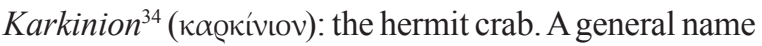
for Anomura Decapoda of the family Paguridae. It is

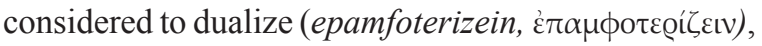
since it looks like karabos but lives inside a shell like ostrakoderma do (HA 529b20-530a27), "carries it about with, feeds inside it, and as it grows it moves on again into a larger one" (HA 548a14-21). Besides this specific meaning, the term karkinion was used for a small karkinos (HA 547b17).

HA 529B20, 530A17, 547B17, 548A14.

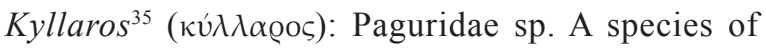
Anomura living inside Nêreitēs, a small gastropod. It is characterized by having "the right pincer smaller than the left one" (HA 530a12). It is difficult to identify a certain species, since there exist some small sized common species of hermit crabs with obviously smaller right pincer.

HA $530 a 12$.

Mikron genos ōsper karkinoi, to eidos homoion tois

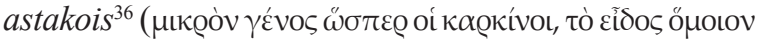

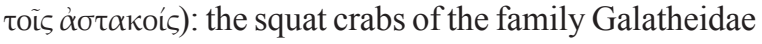
belonging to Anomura. They are a kind "small like crabs but in appearance similar to lobsters" (HA 525b10). HA $525 \mathrm{~b} 10$.

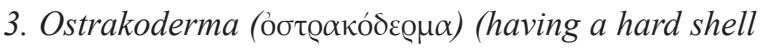
surrounding the body)

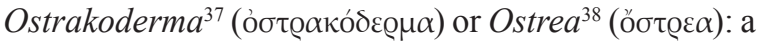
general name for animals protected inside a hard exoskeleton, identified as the current Bivalvia, Gastropoda, Asteroidea, Echinoidea and Ascidiacea. They are described (HA 528a1-20) as "having their fleshy part inside and their hard part outside; the latter would brake 
by cracking but does not crush; there is no hard part

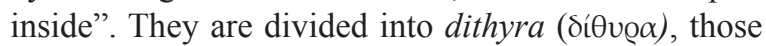

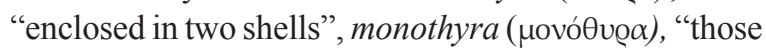
enclosed in one, with the fleshy part exposed, e.g. the limpet" and strombōde ( $\sigma \tau \rho \circ \mu \beta \omega \delta \eta)$, those "having their flesh invisible, except for the head "enclosed in a spiral shell as indicated by their name. The têthya ( modern ascidians are "completely enveloped by their shell and no portion of their flesh is exposed to the outside", while echinoi (عxivot), the sea urchins, "have no fleshy part inside the shell".

Ostrakoderma HA 466b21, 489b14, 490b10, 491b27, 523b9, 527b35, 528b9, 529b21, b23, 531a32, 531b19, 532a7, 534b15, 535a6, a23, 537b25, b31, 538a18, 539a9, 544a16, 546b17, b23, b27, 547b26, 548a22, 549a12, 588b16, 590a19, 599a10, 601a18, 603a12, a24, 606a11, a12, 607b2, b5, 621b9, PA 661a17, a21, 678a30, b11, b22, 679b2, b15, b30, b31, b35, 680a4, a19, a30, 681a32, b1,b12, b31, 683b4, b18, 684b15, b16, b34, 685a5, b26, IA 706a13, b2, 714b8, b14, GA 715b17, 720b6, 731b8, 743b10, 758a28, 761a13, a21, a28, a30, 761b4, b23, 762a29, 763a8, a20, a26, Ostrea HA 487a26, b9, b14, 490b10, 523b12, 525a20, a24, $528 a 1,531 a 15, b 5,547 b 20, b 33,548 a 12,568 a 8,590 a 29, a 31$, $a 32,591 a 13, P A 644 b 10,645 a 3,680 b 7, b 10, b 22, b 23,681 b 10$, GA 761a31, 763a33, b1, b13.

\subsection{Echinoi ('Exĩvoเ) (sea urchins)}

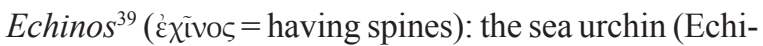
noidea, Echinodermata). A complete description of the sea urchin is given (HA 530a32-531a7 and PA 680a5681a9) and six different species are reported.

HA 528a7, 530a32, b10, b19, b24, 531a4, a6, a15, b8, 535b24, PA 679b28, b34, 680a4, a5, b3, b8, b9, b10, b33, 681a2.

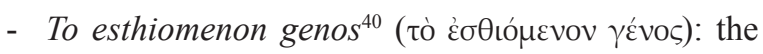
edible stony sea urchin Paracentrotus lividus Lamarck, 1816. It is described as "the edible kind, in which the so-called eggs are large and edible, in large and small ones alike: the eggs are present in them even while still quite small" (HA 530b1). The habit of the species to "always have something fixed on its spines" is pointed out (HA 530b17). HA $530 b 1, b 17$.

- Spatangēs ${ }^{41}(\sigma \pi \alpha \tau \alpha \hat{\gamma} \gamma \eta \varsigma)$ : Echinoidea sp. It is reported (HA 530b5) as a "deep sea and rare species".

HA 530b5.

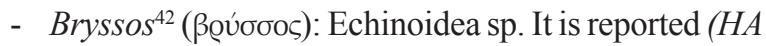
$530 b 5)$ as a "deep sea and rare species". HA $530 b 5$.

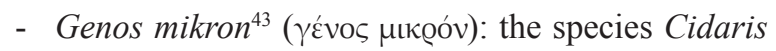
cidaris (Linnaeus, 1758). It is "a kind small in size, bearing large, hard spines ... living in the area of Toronē, several fathoms deep, and some use it as a remedy for strangury" (HA 530b7). C. cidaris, which thrives in sandy bottoms deeper than $30 \mathrm{~m}$, fits with the above description.

HA 530b7, GA 783a20.

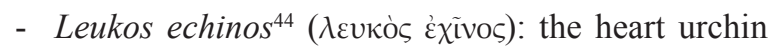
Brissus unicolor (Leske, 1778). They are described as (HA 530b10) "white sea urchins -shells, spines and eggs are all white- longer than the ordinary ones, the spines neither large nor strong, but rather limp". The species B. unicolor, living in sandy bottoms, like in the area of Toroni mentioned in the text, is exactly as described above having a test diameter of up to $13 \mathrm{~cm}$.

HA $530 b 10$.

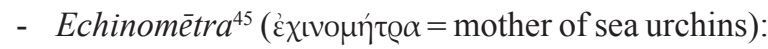
the violet sea urchin Sphaerechinus granularis (Lamarck, 1816). It is "the largest of all in size" (HA 530b6). This common Aegean species is very similar to the common urchins but reaches $15 \mathrm{~cm}$ in test diameter. The species Echinus melo that has been suggested by some authors is yellowish in color and lives in deeper waters, characteristics which have been indicated by Aristotle for the discrimination of other sea urchin species.

HA $530 b 6$.

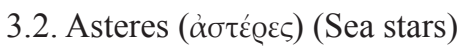

Astēr ${ }^{46}$ ( $\dot{\alpha} \sigma \tau \eta \dot{\varrho}=$ = star): the sea star (Asteroidea, Echinodermata). Most possibly it is one of the very common Aegean species, the normally star-shaped Astropecten aurantiacus (Linnaeus, 1758) or Echinaster sepositus (Retzius, 1783), since Aristotle mentions that "it resembles in shape the stars seen in drawings" (HA 548a7). The predatory activity of the sea star against mollusks is indicated (HA 548a7, PA 681b9).

HA 548a7, PA 681b9.

\subsection{Tèthya (Tí⿴vo)}

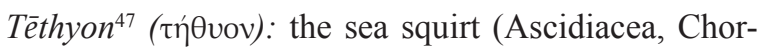
data). It is described (HA 531a9-31) as "the most extraordinary of all these animals, being the only ones whose body is completely hidden inside the shell, the texture of which is between that of skin and shell, and 
consequently cut like hard leather. The animal clings to the rock by its shelly part and has two passages some distance apart". Two kinds are distinguished according to their colour.

HA 528a20, 531a8, a18, a29, 535a24, 547b21, 588b20, PA 680a5, 681a10, a25, GA $763 b 14$.

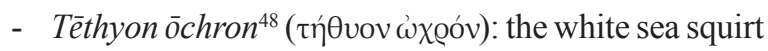
Phallusia mammilata Muller, 1776. This common species has an ochron ( $\omega \chi \varrho o ́ v=$ pale, white-yellow), leathery tunic.

HA 531 a30.

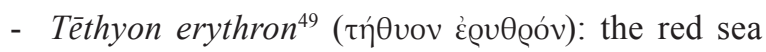
squirt Halocynthia papillosa (Linnaeus, 1767). This common, sciaphilic species is easily recognized by its characteristic erythron ( HA 531 a30.

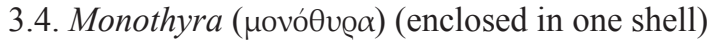

Lepas $^{50}(\lambda \varepsilon \pi \dot{\alpha} \varsigma)$ : the limpet Patella caerulea Linnaeus, 1758. It is described as a "univalve, having its fleshy part exposed" (HA 528a14) "releasing its hold in order to search for food" (HA 528b1) and "living near the surface of the water with Nēreitēs" (HA 547b22).

HA 528a14, b2, 529a31, 530a19, b22, 547b22, 548a27, 590a32, PA 679b25, 680a23.

Lepas agria ${ }^{51}$ ( $\left.\lambda \varepsilon \pi \dot{\alpha} \varsigma \dot{\alpha} \gamma \varrho i ́ \alpha\right)$ or thalattion ous ${ }^{52}$

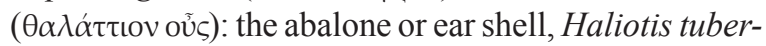
culata Linnaeus, 1758. It is mentioned as "the wild limpet, which is called the ear of the sea and its shell is perforated" (HA 529b15).

Lepas agria HA 529b15, Thalattion ous HA $529 b 15$.

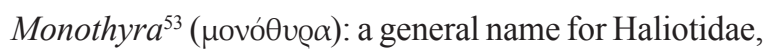
Patellidae and allied families of Gastropoda, i.e. those "enclosed in one shell, having their fleshy part exposed" (HA 528a12).

HA 528a12,a13, b3, b14, 529a25, 603a27, PA 679b17, b23, b27, 680a22, 683b11.

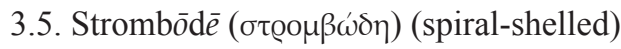

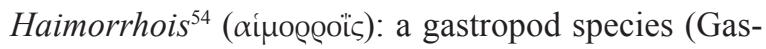
tropoda, Mollusca). Its name, coming from haima ( $\alpha \tilde{\mu} \mu \alpha$

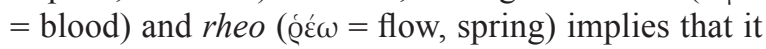
produces a purple dye. However, it is discriminated from porphyra, with which it is reported in a general description of spiral-shelled animals (HA 530a19). Possibly it was a separate name for one of the three species assigned to the name porphyra (see bellow). HA 530a19, a24.

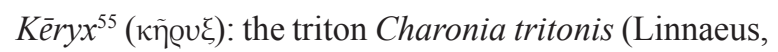
1758 ) and related species. It is usually reported with

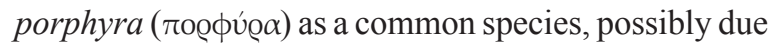
to the fact that both were widely used, not only as food. It has "a rough shell" (HA 528a24), is "long-lived" (HA $547 b 8)$ and "the smallest individuals may host hermit cabs" (HA 548a19). It was used in antiquity as food, for the construction of trumpets and as jars, after removing its internal axis.

HA 524b12, 527a24, a28, 528a10, a24, a30, 529a7, 530a5, $a 14,544 a 15,546 b 25, b 26,547 b 2, b 8,548 a 19,549 a 17, P A$ 679b14, b20, 683b13, IA 706a16, GA 761b31, $763 b 9$.

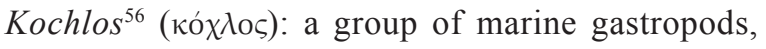
other than the well known species such as the roeфv́@ the $\kappa \eta \dot{\emptyset} \varrho \xi$, etc. (...the purpura, the trumpet-shell, the sea

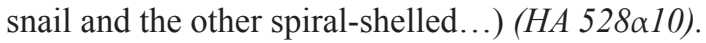

HA 528a1, a10, 529a2, a17, a24, b3, 530a27, PA 678b24, $679 b 4, b 14$.

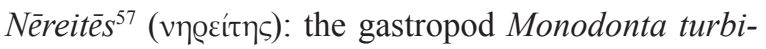
nata (Born, 1780) and related species. It is described as "having a smooth, large and rounded shell, resembling to keryx" (HA 530a12). It is said to "live near the surface with the limpets, moving about when the sea is calm" (HA 530a12) and that "they can host small karkinia" (HA 530a7). M. turbinata is the largest of all the Trochidae species (of the genera Monodonta and Gibbula) living in the mediolittoral zone and it has been used for food since the neolothic period.

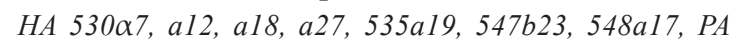
$679 b 20$.

Porphyra $^{58}$ (тоффú@ $\alpha=$ purpura): the purple dye murex Bolinus brandaris (Linnaeus, 1758), the banded murex Hexaplex trunculus (Linnaeus, 1758) and the red-mouth purpura Stramonita (= Thais) haemastoma (Linnaeus, 1767). All these species were used in antiquity for food but mainly as sources for the extraction of the purple dye. Aristotle gives a lot of information on these valuable animals: he says that "there are several species differing in external morphology and in the color of the dye" (HA 547a4); he gives a detailed description of the way the dye is extracted and prepared for use (HA 547a 15); he mentions the egg-masses they lay, considering them as kind of refuse ( $H A$ 546b19), etc.

HA 528a10, 529a6, 530a5, a25, 532a9, 535a7, 544a15, $546 b 18, b 23, b 32, b 33,547 a 4, a 21, b 1, b 2, b 6, b 8, b 9, b 24, b 32$, 568a9, 590b2, 599a11, a17, 603a13, a15, 621b11, 661a21, PA 
679b14, b19, IA 706a15, GA 761b31, 763b9, 794a21, 795b11, $797 a 5$.

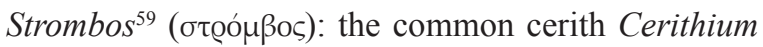
vulgatum Bruguiere, 1792 and related species. It is reported in comparison with Nêreitēs concerning its size: the hermit crabs living in strombos are more elongated than those living in nêreitēs (HA 530a6). It was "used as bait for porphyra, the latter having the strength to bore through its shell" (PA 661a21). Common ceriths, which are very common in the mediolittoral and upper sublittoral of the Aegean, have been widely consumed as food since the Neolithic period.

HA 492a17, 530a6, 226, 548a18, 621a23, PA $685 a 18$.

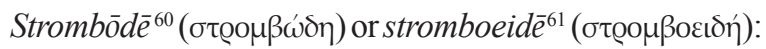
a general name for spiral-shelled marine animals (Gastropoda Mollusca). "They move and creep about" (HA 528a33), and "they have an operculum which serves the purpose of the second valve in the bivalves" (HA 530a22). There are several kinds "the porphyres, the kērykes and the remaining spiral-shelled" (HA 528a11).

Strombōdē HA 528a11, a33, b5, b8, b13, 529a15, 530a22, b21, 531a1, 547b4, PA 679b14, b16, b17, b26, 680a22, 683b12, 684b16, b20, b34, 685a10, a11, IA 706a13, b1, GA $763 a 22$. stromboeidē HA $528 b 17$.

3.6. Dithyra ( $\delta i \operatorname{vo\alpha } \alpha)$ (enclosed in two shells, bivalves)

Balanos $^{62}$ ( $\left.\beta \alpha \dot{\lambda} \lambda \alpha v o s\right)$ : the bivalve Pholas dactylus Linnaeus, 1758 . It is only reported as a stationary animal "living in rock cavities or crevices along with the sea squirts" (HA 547b22). The name $\beta \alpha \alpha \lambda \alpha v o s$, attributed originally to the oak acorn, indicates this species, which resembles in various aspects this fruit; it has an externally sculptured shell bearing concentric and radiating ribs which are roughest in front in order to assist drilling into the substrate; the siphons protruding from the shell, like the oak fruit from its cup, are long, united, covered by a horny sheath.

HA 535a25, 547b22.

Chême $\bar{e}^{63}(\chi \eta \dot{\mu \eta})$ : the common Noah's arc shell Arca noae Linnaeus, 1758 and the related species. The name chēme ( $\chi \eta \dot{\mu} \mu$ from $\chi \alpha \dot{\sigma} \sigma \mu \alpha=$ gap, chasm) indicates the space existing between the umbones which are far apart in dorsal view. They are reported once by Aristotle as "taking their rise in sandy places together with conchai, sōlēnes and ktenes" (HA 547a13). He does not give any further information of these animals, but Xenocrates in

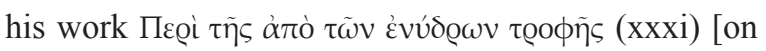
food from aquatic animals] writes that the coarser of them are "elongated, having a roughness when opened, just like the cup of the acorn", obviously indicating the straight hinge with the numerous small teeth and that "they are radially ribbed, with extra roughness, on their shell", just like Arca.

$$
\text { HA } 547 a 13 .
$$

Conch $^{64}$ (кó $\left.\gamma \chi \eta\right)$ : a general name for smooth-shelled bivalves, such as tellins (Tellinidae), trough shells (Mactridae) or wedge shells (Donacidae). They are listed with razor shells and mussels as examples of ostrakoderma "having a smooth shell" (HA 528a21-27) and they are reported to "take their rise in sandy places" (HA 547a13).

HA 528a22, 530a11, 547b13, b20, 548a5, 614a28, $622 b 2$.

- $\operatorname{Galax}^{65}(\gamma \alpha \dot{\alpha} \lambda \alpha \xi)$ : a species belonging to one of the families Donacidae, Tellinidae and Mactridae. It is not possible to discriminate which of the three was known under this certain name, since it is just reported as "a kind of conchai, called by some galakes". The name itself indicates a milky white shell but such morphs exist in all the above groups which present a great variation in shell colour (HA 528a23).

HA $528 a 23$.

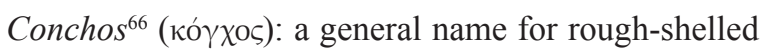
bivalves, i.e. cockles (Cardiidae), venus clams (Veneridae), and allied species.

HA 528a24, a25, a26.

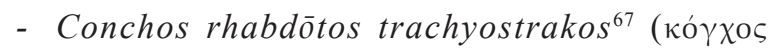

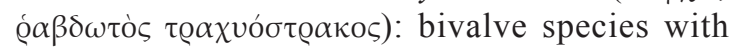
"rough, radially ribbed shells", such as the cockles of the family Cardiidae (HA 528a25).

HA $528 a 25$.

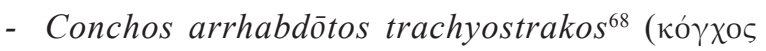

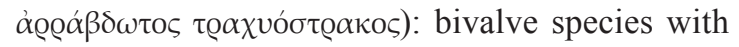
"rough, not radially ribed shells", such as the venus clams of the family Veneridae (HA 528a26). HA $528 a 26$.

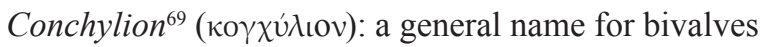
(Bivalvia, Mollusca). They are usually mentioned as food for other marine organisms such as the purple shellfish (HA 547b7), the marine turtles (HA 590b4), and the octopuses (HA 591a1).

HA 519b21, 547b7, 590b4, 591a1, 622a7, b17, PA 661a22. 
$\operatorname{Dithyra}^{70}(\delta i \theta v \varrho \alpha)$ : a general name for bivalves (Bivalvia, Mollusca). They are ostrakoderma "enclosed in two shells" (HA 528a12) which may be "smooth" or "rough, ribbed, thick or thin, moving or stationary" (HA 528a22-34).

HA 528a11, a12, a14, a17, b4, b15, 529a25, a31, 530a22, 603a27, PA 679b16, b17, b24, b25, b27, 680a23, a25, 683b11, b14.

Kteis $^{71}(\kappa \tau \varepsilon i \zeta=\mathrm{comb})$ : the scallops of the family Pectenidae. It is emphasized that "it has a radially ribbed shell" (HA 528a25), "it can actually fly, because it often jumps out of the device in which it was caught" (HA $528 a 30)$, and that "they take their rise in sandy places" (HA 547b16).

HA 528a15, a25, a31, 531b8, 535b26, 547b14, b24, b32, 599a14, a18, 603a21, a22, 607b2, PA 679b25, 680b23, 683b15, 621b10, GA $763 b 12$.

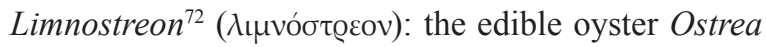
edulis Linnaeus, 1758. It is described as "rough-shelled and thick-lipped" (HA 528a23), "being born in muddy places" (HA 547b12), and hosting little shrimps or crabs (HA 547b29).

HA 528a23, a30, 547b11, b29, GA 763a30, b12.

$\operatorname{Mys}^{73}$ ( $\left.\mu \tilde{v} \varsigma\right)$ : the Mediterranean mussel Mytilus galloprovincialis Lamarck, 1819. It is a "thin lipped bivalve, unlike the oysters" (HA 528a29), and "they grow, like onions, by side-shoots, the smaller ones growing on the sides of the original ones" (GA 761b31). Here the formation of mussel beds is well described.

HA 528a15, a22, a29, 547b11, PA 679b26, 683b25, GA $761 b 30,763 b 12$.

$\operatorname{Pinna}^{74}(\pi i v v \alpha)$ : the noble pen shell Pinna nobilis Linnaeus, 1758. It is a "rough-shelled bivalve" (HA 528a24), "they grow up erect held by their byssos, in sandy and muddy places; they have inside a pinnaguard, some of them a small shrimp and other a small crab; and if they are deprived of it they quickly perish" (HA 547b15).

HA 528a24, a26, a33, 547b15, b28, 548a5, 588b15, GA $763 b 8$.

Sōlēen $n^{75}(\sigma \omega \lambda \dot{n} v=$ tube): the razor shells of the family Solenidae. They "have a smooth shell" (HA 528a18) and in contrast to scallops, which are closed at the one end and opened at the other, "they are closed at both sides" (PA 683b17), possibly indicating the adductor muscle which is located by the mantle cavity, near the end of the each valve. Moreover, they "take their rise in sandy places" (HA 547b13).
HA 528a18, a22, 535a14, 547b13, 548a5, 588b15, PA $683 b 17$.

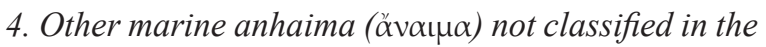
above major groups

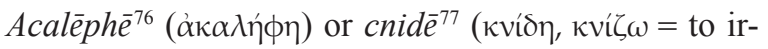
ritate): the sea anemones (Actiniaria, Anthozoa, Cnidaria). A detailed description is given (HA 531a31) and two species are distinguished.

Akalēphē HA 487a25, b12, 531a31, b10, 588b20, 590a27, a31, cnide HA 548a23, a24, 681a36.

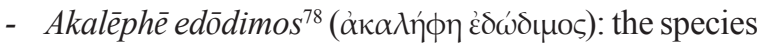
Anemonia viridis (Forskal, 1775) described as "small, edible, living on smooth, broad and flat surfaces, able to detach and move around".

HA 531b10, $548 a 22$.

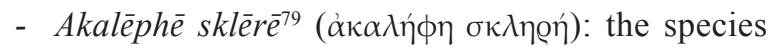
Actinia equina (Linnaeus, 1758) described as "bigger and harder, living in rocks crevices and never detached from the rock".

HA 531b10, 548a22.

Aidoion andros ${ }^{80}$ ( $\alpha$ ìooĩov àvo@ós) (looking like aidoion andros): the echiuran Bonnelia viridis Rolando, 1821 (Echiura). It is mentioned as a "rare species not easily classified, although observed by experienced fishermen; ... it is similar in shape and size to the male penis having two fins instead of the testicles" (HA 532b23). The female of $B$. viridis reaches $15 \mathrm{~cm}$ in length and its proboscis has a forked tip, the two branches of which must have been called fins by Aristotle, just like the tentacles of the cuttlefish.

HA $532 b 23$.

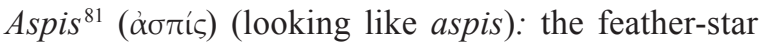
Antendon mediterranea (Lamarck, 1816) (Crinoidea, Echinodermata). It is described as a "rare species not easily classified, although observed by experienced fishermen; ... it looks like aspis ( $\alpha \sigma \pi i$ i meaning here a poisonous snake species well known at that age), it is red in colour and bears densely arranged fins" (HA 532b22). The common Mediterranean crinoid A. mediterranea must have been associated with a snake due to the waving movement of its arms that bear many branches.

HA $532 b 22$.

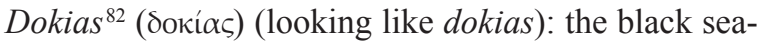
cucumber Holothuria forskali Delle Chiaje, 1823 
(Holothurioidea, Echinodermata). It is mentioned along with aidoion and aspis as a "rare species not easily classified, although observed by experienced fishermen; ... it is like a relatively long and stout bar, black, round and has the same thickness throughout its length" ( $H A$ $532 \mathrm{b21}$ ). The description fits perfectly to this common Mediterranean species of sea-cucumbers, which may reach $40 \mathrm{~cm}$ in length.

HA $532 b 21$.

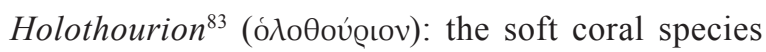
Veretillum cynomorium (Pallas, 1766) (Anthozoa, Cnidaria). According to Aristotle it is "an unattached, though not moving animal, not having any power of sensation, living like a plant unattached to the soil" (HA 487b14). Moreover, "it differs from sponges only slightly in being unattached" (HA 681a17). This description fits well with the above common species which resembles sponges actually in having a spongy internal structure and lives in sandy bottoms loosely held in the sediment. Its elongated shape and erect habit lies behind the name holothourion, óloӨov́pıv

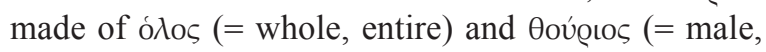
acute, fierce).

HA 487b15, PA 681a17.

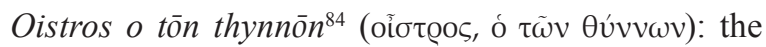
parasitic copepods (Copepoda, Crustacea) of the genus Caligus commonly found on tuna fish. According to the description it is "found around the fins of tuna, it is like a scorpion and about the size of a spider" (HA 557a27). The species of the genus Caligus conform to this description.

HA 557a27, 602a28.

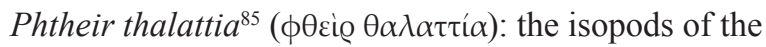
family Cymothoidae (Isopoda, Crustacea). Their description as "lices ( $\phi \theta \varepsilon i ́(\varepsilon \varsigma)$ found on fishes, resembling woodlice, except that they have a flat tail, and they are mostly found on the red mullet" (HA 557a21) indicates these common fish parasites. The most common species in the Mediterranean are Nerocila bivittata (Risso, 1816) and Anilocra physodes (Linnaeus, 1758).

HA 537a5, 557a22, a25, 602b29.

Pneumōn ${ }^{86}$ ( $\left.\pi v \varepsilon v ́ \mu \omega v\right)$ : the dead man's finger Alcyonium palmatum Pallas, 1766 (Anthozoa, Cnidaria). It is only mentioned once (PA 681a18) along with holothourion as "differing only slightly from sponges in being unattached. They have no power of sensation but they live just as if they were plants unattached to the soil". As mentioned for holothourion it has a spongy internal structure as well, justifying the name $\pi v \varepsilon v ́ \mu \omega v$ (= lung) and lives loosely held in sandy bottoms.

$$
\text { HA 548a11, PA 681a17. }
$$

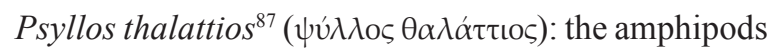
(Amphipoda, Crustacea). They are mentioned as attacking in great numbers the fish caught by the fishermen when they are left in the water for a while before brought on the surface, or even crowding together around the bait, provided that it consist of fish, forming a ball around it (HA 537a8). The above information and the name $\psi \dot{v} \lambda \lambda$ os (= flea), borrowed from the known insects, indicates the marine amphipods, which besides an external superficial similarity, share the ability of jumping (at least the littoral species of the group). HA $537 a 6$.

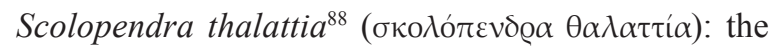
fire-worm Hermodice carunculata (Pallas, 1766) (Polychaeta, Annelida). It is mentioned that "there exist marine scolopendras similar to the terrestrial ones but slightly smaller in size, occurring in rocky places" which "compared to the land millipedes, they are redder and have more numerous and more delicate feet" (HA 505b14). They are said to "bite, not with the mouth, but apparently with the whole body, like the sea anemone, and to turn its inside out when it swallows the hook, in order to expel it" (HA 621a6). This warm water polychaete, very common in the Eastern Mediterranean, but missing from the western basin, may reach $30 \mathrm{~cm}$ in length. It has numerous parapodia, bearing red gills at their base. It can easily extent and retract its pharynx and when touching the skin it causes a burning irritation.

HA 505b14, 621a6.

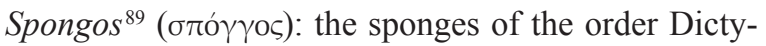
oceratida (Porifera) including the commercial bath species. They are described as "living attached on the substrate, being black when alive, before cleaned and washed, providing home for animals like worms and crustaceans, being able to grow up again in case it gets broken off" (HA 548b1-549a13) as well as being the most primitive animals "resembling very much the plants" (HA 588b21), "having however, a sort of sensation" (HA 548b10) and "receiving food through the big passages on its upper part" (HA 548a30). Five different kinds are distinguished (HA 548b1-549a13).

HA 487b9, 548a23, a28, a32, 549a7, a10, a10, a12, 588b20,

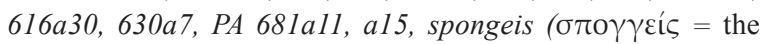
sponge fishermen) HA $620 b 34$. 
- Aplysias $^{90}$ ( $\left.\dot{\alpha} \pi \lambda v \sigma i \alpha \varsigma\right):$ the black Ircinia Sarcotragus muscarum Schmidt, 1864, called "wild sponge" by the sponge fishermen. The description given (HA 549a4) fits perfectly to this species, since it can not be cleaned and used as a bath sponge, though it looks very much like the common bath sponges while it is black and in cross section it has large canals, and dense skeleton. Moreover, "compared to the bath sponges it is stickier and more difficult to be torn, looking like a lung".

HA 549 a4.

- $\operatorname{Manos}^{91}$ ( $\left.\mu \alpha v o ́ \varsigma\right)$ : the honey comb Hippospongia communis (Lamarck, 1813). It is only mentioned by its name ( $\mu \alpha v o ́ \varsigma=$ loose) (HA 548b1) indicating the loose structure of this species which bears numerous and large canals, and for "reaching the largest size of all kinds" (HA 548b19), which is true for this species sometimes passing $30 \mathrm{~cm}$ in diameter. HA 548b1, b19.

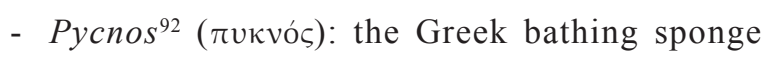
Spongia officinalis Linnaeus, 1759. The name ( $\pi$ vкv́s $=$ dense, close-textured) and the comment that "they become the softest in the area around Lycia" indicates the best quality bath sponge of the species $S$. officinalis.

HA 548b1, b9, b20, b25.

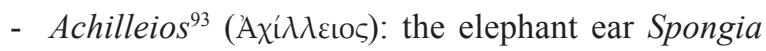
agaricina Pallas, 1766. It is mentioned as "the finest, most closely textured and strongest and the rarest species of all, used for lining helmets and greaves for protection, deadening the noise of blows on them" (HA 548b1). This thin, cup-shaped, strong and delicate sponge fits well to the description. HA 548b1, b20.

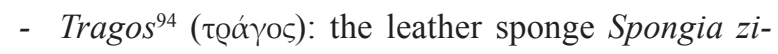
mocca Schmidt, 1862. It is mentioned as "closetextured sponges which are specially hard and rough,

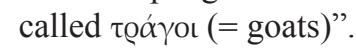

HA $548 b 5$.

\section{Discussion}

Aristotle's major genera and higher taxa

All marine anhaima encountered in Aristotle's zoological works are correlated with current marine invertebrate taxa. As a result, a generalized correlation of Aristotle's major genera of marine anhaima (Fig. 1) with current higher taxa was obtained (Table 1).

Obviously, there was not a direct correlation, since the main taxonomic character he used for their delimitation was the arrangement of the soft and hard parts in the animal body. However, he distinguished current cephalopods (his Malakia) and decapods (his Malakostraka) as separate groups (including stomatopods in the latter). Malakostraka was not homogenous, including some

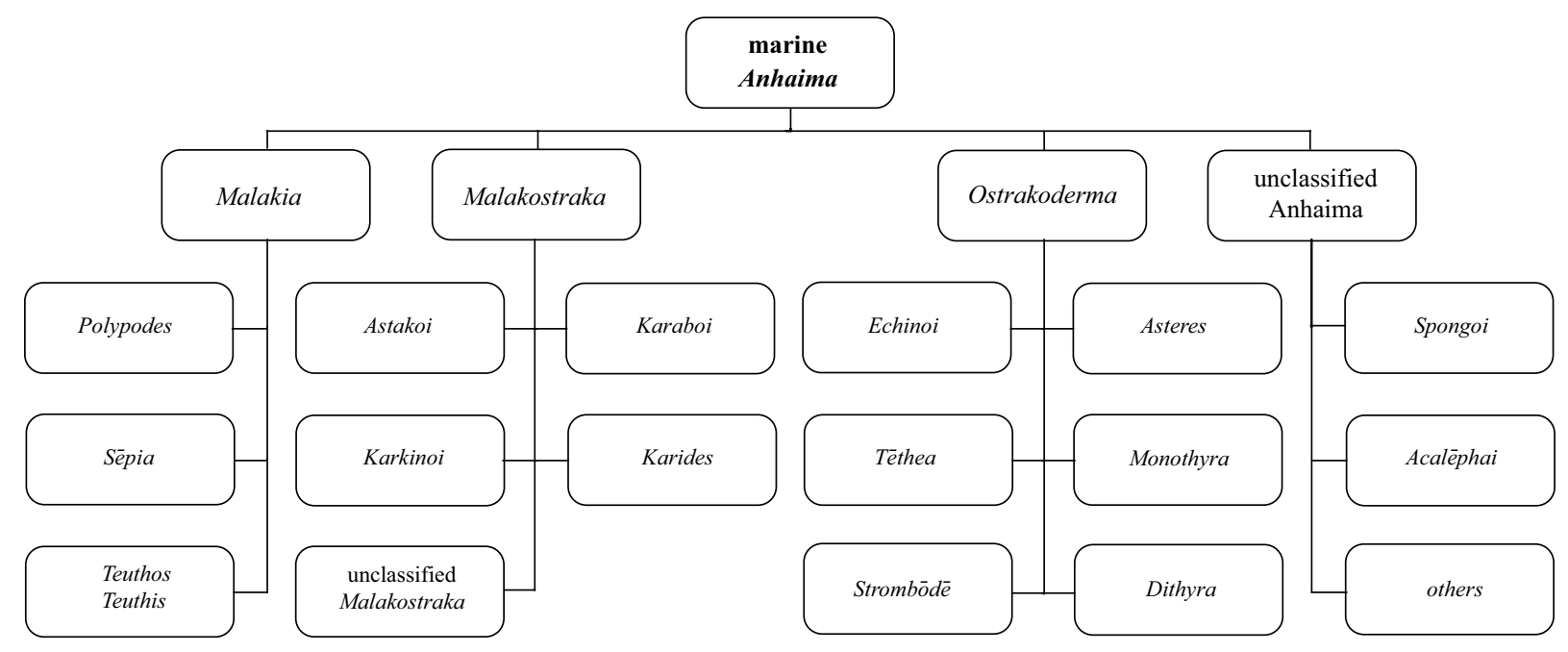

Fig. 1. Aristotle's classification of marine bloodless animals. 
major genera itself (PA 683b26), such as astakoi, karaboi, karides and karkinoi corresponding to the current Macrura Reptantia (the first two), Natantia and Brachyura respectively. Echinoderms were not recognized as a group, since two of their classes (Echinoidea and Asteroidea) were put in Ostrakoderma and other two (Crinoidea and Holothourioidea) remained unclassified. Several marine bloodless animals remained out of the three major genera; some of these unclassified anhaima, i.e. the sessile sponges, anthozoans and ascidians were distinguished for their resemblance to plants and ranked at the early stages of "nature's transition from plants to animals" (PA 681a10-b9). Aristotle's principle of downward classification, to which Linnaeus largely adhered, dominated in taxonomy up to the eighteenth century (Mayr and Ashlock, 1991).

\section{Classical animal names and their assignment to current taxa}

The 94 different animal names or descriptive phrases encountered were assigned to 85 current marine invertebrate taxa at different category levels (Table 2, Figure 2 ). The number of taxa is lower in comparison to the number of animal names mostly because some animals appeared in the texts with more than one name, e.g. heledōne and nautilos. The majority of the animals $(58 \%)$ were assigned to species level taxa and the remaining to supraspecific taxa. In malakia, a group including mostly incessant commercial species, species level taxa were almost exclusively identified.

Table 1. Correlation of Aristotle's groups with current higher taxa, based on the identification of all marine anhaima encountered in his zoological works.

\begin{tabular}{ll}
\hline $\begin{array}{l}\text { Aristotle's major } \\
\text { marine } \text { Anhaima } \text { groups }\end{array}$ & $\begin{array}{l}\text { Current marine invertebrate } \\
\text { higher taxa }\end{array}$ \\
\hline Ostrakoderma & $\begin{array}{l}\text { Mollusca (Bivalvia and Gastropo- } \\
\text { da), Echinodermata (Echinoidea } \\
\text { and Asteroidea) Ascidiacea }\end{array}$ \\
\hline Malakia & Mollusca (Cephalopoda) \\
\hline Malakostraka & $\begin{array}{l}\text { Malacostraca (Decapoda and } \\
\text { Stomatopoda) }\end{array}$ \\
\hline other marine Anhaima & Porifera \\
\hline & Cnidaria \\
\hline & Echiura \\
\hline & Polychaeta \\
\hline & Copepoda \\
\hline $\begin{array}{l}\text { Malacostraca (Amphipoda and } \\
\text { Isopoda) Echinodermata (Crinoi- } \\
\text { dea and Holothurioidea) }\end{array}$ \\
\hline
\end{tabular}

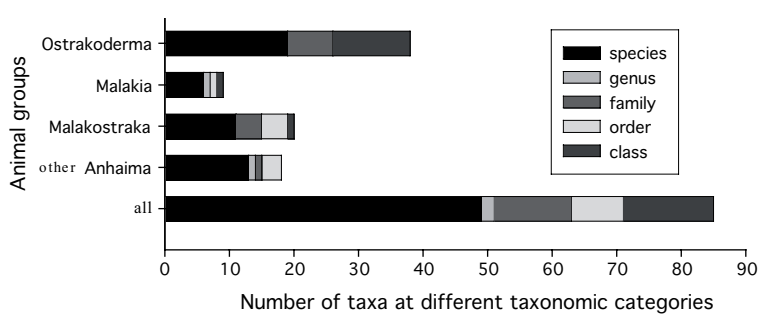

Fig. 2. Numbers and taxonomic level of marine invertebrate taxa recognized in Aristotle's zoological works.

The fact that Aristotle himself did not undertake the task to name all animals he examined has been considered as a difficulty for the construction of a full list of all animals he recorded by later researchers (Louis, 1971). However, although he did not purposely introduce new names or terms where they did not exist, modern marine biology owes to Aristotle a lot of names that appear for the first time in his writings (Table 2). Sixty-six out of the 94 names or descriptive phrases (70\%) attributed to marine invertebrates by Aristotle were recorded for the first time in his zoological works ( $4^{\text {th }}$ century B.C.). The remaining had been recorded in non-biological texts by earlier authors, some of which lived in the $5^{\text {th }}$ century, such as the comedians Philyllius, Epicharmus, Aristophanes (astakos, balanos, pinna, spatangēs, sōlēn, teuthis) and the father of medical science Hippocrates (haimorrhois, pagouros). A few others have first appeared in the texts of the $6^{\text {th }}$ century, e.g. in Aeschylus tragedies (konchos, mys), or even earlier, in the $8^{\text {th }}$ century, in the first written documents of Greek literature, the Homeric epics (polypous, spongos). A series of names were used, as mentioned earlier, in the formation of Latin scientific names, successfully or not. Some examples are Malakostraka, Aplysina, Balanus, Brissus, Eledone, Cnidaria, Crangon, Nautilus, Holothurioidea, Ostrea, Pinnotheres, Scyllarus, and Teuthoidea.

\section{Aristotle's scientific knowledge of marine invertebrate diversity}

It is clear that, with few pelagic exceptions, Aristotle's marine anhaima were benthic invertebrates. This seems quite reasonable since benthic organisms represent $98 \%$ versus $2 \%$ of the pelagic ones in the marine ecosystem (Gaston and Spicer, 1998).

An estimation of the highly recorded animal names in Aristotle's works showed that they, unsurprisingly, included those of the three major genera (ostrakoderma, malakia, malakostraka) and some of the most common 
Table 2. Classification of recent invertebrate taxa identified in Aristotle's zoological works. Asterisks indicate that an animal or animal name had not previously appeared in written texts. Numbers in parentheses correspond to the numbered comments given in the text.

\begin{tabular}{|c|c|c|c|}
\hline Recent taxa & & Classical names & $\begin{array}{l}\text { Transl Raspaxilla iterated classical } \\
\text { names }\end{array}$ \\
\hline \multirow[t]{7}{*}{ Porifera } & Demospongiae & & \\
\hline & Dictyoceratida (89) & 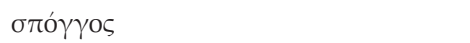 & spongos \\
\hline & Hippospongia communis (91) & 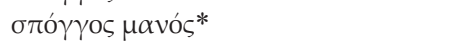 & spongos manos \\
\hline & Sarcotragus muscarum (90) & $\dot{\alpha} \pi \lambda v \sigma i \alpha \varsigma^{*}$ & aplysias* \\
\hline & Spongia agaricina $(93)$ & 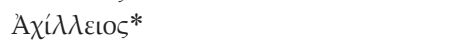 & Achilleios* \\
\hline & Spongia officinalis (92) & 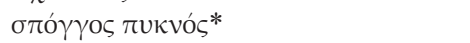 & spongos pycnos* \\
\hline & Spongia zimocca $(94)$ & 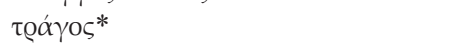 & tragos ${ }^{*}$ \\
\hline \multirow[t]{6}{*}{ Cnidaria } & Anthozoa & & \\
\hline & Actinia equina (79) & $\dot{\alpha} \kappa \alpha \lambda \eta ́ \phi \eta ~ \sigma \kappa \lambda \eta \varrho \eta^{*}$ & acalēphē sklērēe \\
\hline & Actiniaria $(76,77)$ & $\dot{\alpha} \kappa \alpha \lambda \eta \dot{\phi} \eta *, \kappa v i ́ \delta \eta *$ & acalēphē $^{-}$, cnide $\bar{e}^{*}$ \\
\hline & Alcyonium palmatum (86) & $\pi v \varepsilon v ́ \mu \omega v^{*}$ & pneumōn* \\
\hline & Anemonia viridis (78) & 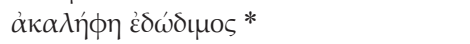 & acalēphē edōdimos* \\
\hline & Veretillum cynomorium (83) & 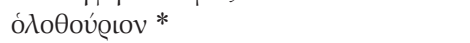 & holothourion* \\
\hline \multirow[t]{2}{*}{ Annelida } & Polychaeta & & \\
\hline & Hermodice carunculata (88) & 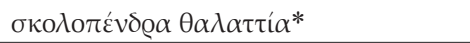 & scolopendra thalattia* \\
\hline Echiura & Bonnelia viridis $(80)$ & 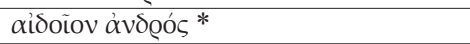 & aidoion andros ${ }^{*}$ \\
\hline \multirow[t]{39}{*}{$\overline{\text { Mollusca }}$} & Gastropoda & & \\
\hline & Bolinus brandaris (58) & 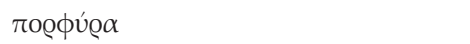 & porphyra \\
\hline & Cerithium vulgatum (59) & 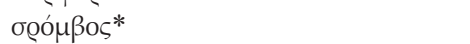 & strombos* \\
\hline & Charonia tritonis (55) & $\kappa \tilde{\eta} \varrho u \xi *$ & kēryx ${ }^{*}$ \\
\hline & Gastropoda $(60,61)$ & 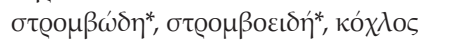 & strombōdē $\bar{e}^{*}$, stromboeide $\bar{e}^{*}$, kochlos \\
\hline & Haliotis tuberculata $(51,52)$ & $\lambda \varepsilon \pi \dot{\alpha} \varsigma \alpha \dot{\alpha} \gamma \varrho \dot{\alpha} \alpha *, \theta \alpha \lambda \alpha \dot{\tau} \tau \tau$ เov oũ $\varsigma$ & lepas agria*, thalattion ous \\
\hline & Hexaplex trunculus (58) & 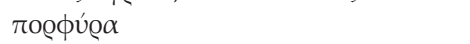 & porphyra \\
\hline & Monodonta turbinata (57) & 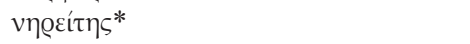 & nēreitēs* \\
\hline & Patella caerulea $(50)$ & $\lambda \varepsilon \pi \alpha ́ \varsigma$ & lepas \\
\hline & Stramonita haemastoma (58) & 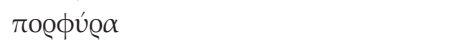 & porphyra \\
\hline & Gastropoda un. sp. (54) & 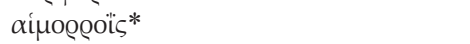 & haimorrhois \\
\hline & Gastropoda un. spp. (56) & 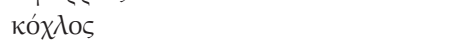 & kochlos \\
\hline & Gastropoda (univalves) (53) & $\mu$ ovó $\theta v \varrho \alpha^{*}$ & monothyra* \\
\hline & Bivalvia & & \\
\hline & Arca noae (63) & $\chi \eta \dot{\mu \eta}$ & chēmē \\
\hline & Bivalvia $(69,70)$ & 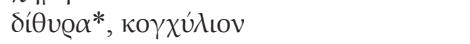 & dithyra*, conchylion \\
\hline & Cardiidae (67) & 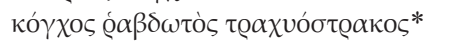 & conchos rhabdōtos trachyostrakos \\
\hline & Donacidae (64) & кó $\gamma \chi \eta$ & conchē \\
\hline & Mactridae (64) & кó $\gamma \chi \eta$ & conchē \\
\hline & Mytilus galloprovincialis (73) & $\mu \tilde{v} \varsigma$ & mys \\
\hline & Ostrea edulis (72) & $\lambda \iota \mu$ ó $\tau \varrho \varepsilon{ }^{*} *$ & limnostreon* \\
\hline & Pectinidae (71) & $\kappa \tau \varepsilon i \zeta$ & kteis \\
\hline & Pholas dactylus (62) & $\beta \alpha \dot{\lambda} \lambda \alpha$ vo & balanos \\
\hline & Pinna nobilis (74) & $\pi i ́ v v \alpha$ & pinna \\
\hline & Solenidae (75) & $\sigma \omega \lambda \dot{\eta} v$ & sōlēn \\
\hline & Tellinidae (64) & кó $\gamma \chi \eta$ & conchē \\
\hline & Veneridae (68) & 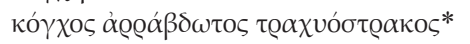 & conchos arrhabdōtos trachyostrakos \\
\hline & Bivalvia un. spp. (66) & 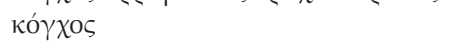 & conchos \\
\hline & Bivalvia un. spp. (65) & $\gamma \alpha \dot{\lambda} \alpha \xi^{*}$ & galax $^{*}$ \\
\hline & Cephalopoda & & \\
\hline & Argonauta argo $(7,8,9)$ & 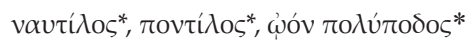 & mautilos ${ }^{*}$, pontilos ${ }^{*}$, oon polypodos ${ }^{*}$ \\
\hline & Cephalopoda (1) & $\mu \alpha \lambda \alpha^{\prime} \kappa \iota \alpha^{*}$ & malakia* \\
\hline & Eledone moschata $(4,5,6)$ & $\dot{\varepsilon} \lambda \varepsilon \delta \omega \nu \eta{ }^{*}, \beta \mathrm{o} \lambda \mathrm{i} \tau \alpha \mathrm{\iota} v \alpha^{*}, \mathrm{o} \zeta \mathrm{o} \lambda \iota \varsigma^{*}$ & eledōnē ${ }^{*}$, bolitaina ${ }^{*}$, ozolis ${ }^{*}$ \\
\hline & Loligo vulgaris (14) & $\tau \varepsilon v \theta i \varsigma \zeta$ & teuthis \\
\hline & Nautilus sp. (10) & 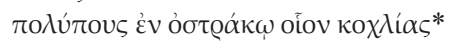 & polypous en ostrakō oion cochlias* \\
\hline & Octopoda (2) & $\pi о \lambda u ́ \pi o v \varsigma$ & polypous \\
\hline & Octopus vulgaris (3) & 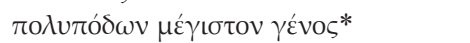 & polypodōn megiston genos* \\
\hline & Sepia officinalis $(11,12)$ & $\sigma \eta \pi i ́ \alpha, \sigma \eta \pi i ́ \delta ı v$ & sēpia, sēpidion \\
\hline & Todarodes sagtitatus (13) & $\tau \varepsilon \tilde{v} \theta o \varsigma^{*}$ & teuthos ${ }^{*}$ \\
\hline
\end{tabular}




\begin{tabular}{|c|c|c|c|}
\hline Arthropoda & $\begin{array}{l}\text { Crustacea } \\
\text { Alpheidae (25) } \\
\text { Amphipoda (87) } \\
\text { Anomura (34) } \\
\text { Brachyura (26) } \\
\text { Calappa granulata (31) } \\
\text { Caligus sp. (84) } \\
\text { Cancer pagurus (30) } \\
\text { Cymothoidae, Isopoda (85) } \\
\text { Galatheidae (36) } \\
\text { Homarus gammarus }(16) \\
\text { Maja squinado }(29) \\
\text { Malacostraca (15) } \\
\text { Natantia (20) } \\
\text { Natantia un. sp. }(22) \\
\text { Ocypode cursor }(28) \\
\text { Paguridae (35) } \\
\text { Palinurus elephas }(18,19) \\
\text { Penaeidae un.sp. }(21) \\
\text { Pinnotheres pisum }(32,33) \\
\text { Polybius depurator }(27) \\
\text { Pontonia pinnophylax }(24) \\
\text { Scyllarus arctus }(17) \\
\text { Squilla mantis }(23)\end{array}$ & 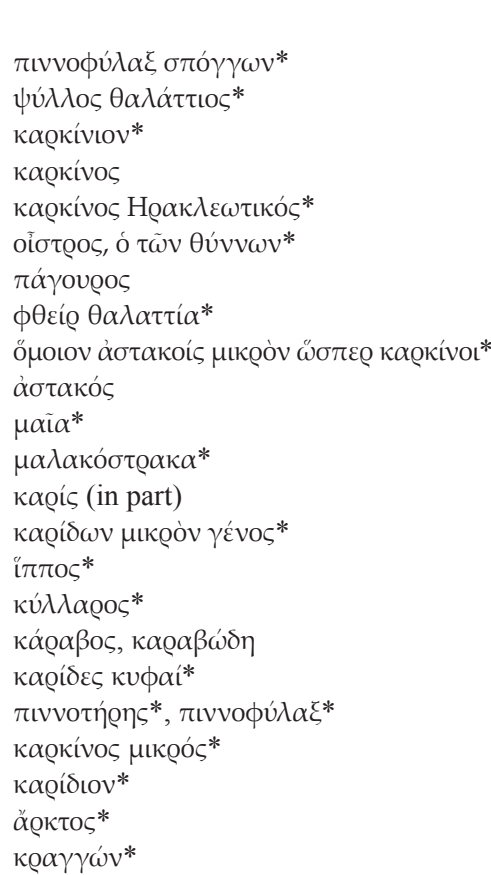 & $\begin{array}{l}\text { pinnopfylax spongōn* } \\
\text { psyllos thalattios* } \\
\text { karkinion* } \\
\text { karkinos } \\
\text { karkinos Herakleotikos* } \\
\text { oistros o tōn thynnōn* } \\
\text { pagouros } \\
\text { phtheir thalattia* } \\
\text { * omoion astakois, micron ōsper karkinoi* } \\
\text { astakos } \\
\text { maia* } \\
\text { malakostraka* } \\
\text { karis (in part) } \\
\text { karidōn micron genos* } \\
\text { hippos* } \\
\text { kyllaros* } \\
\text { karabos, karabōdē } \\
\text { karides kyfai* } \\
\text { ponnotēēē*, pinnophylax* } \\
\text { karkinos mikros* } \\
\text { karidion* } \\
\text { arktos* } \\
\text { krangōn* }\end{array}$ \\
\hline Echinodermata & $\begin{array}{l}\text { Crinoidea } \\
\text { Antendon mediterranea (81) } \\
\text { Asteroidea } \\
\text { Asteroidea (46) } \\
\text { Echinoidea } \\
\text { Brissus unicolor (44) } \\
\text { Cidaris cidaris (43) } \\
\text { Echinoidea (39) } \\
\text { Echinoidea un.sp. (42) } \\
\text { Echinoidea un.sp. (41) } \\
\text { Paracentrotus lividus (40) } \\
\text { Shaerechinus granularis (45) } \\
\text { Holothurioidea } \\
\text { Holothuria forskali (82) }\end{array}$ & 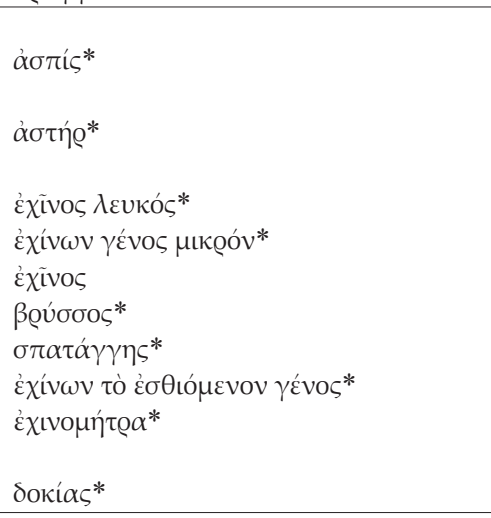 & $\begin{array}{l}\text { echinos leucos* } \\
\text { echinōn genos mikron* } \\
\text { echinos } \\
\text { bryssos }^{*} \\
\text { spatangēs* } \\
\text { echinōn to esthiomenon genos* } \\
\text { echinomētra* }\end{array}$ \\
\hline Chordata & $\begin{array}{l}\text { Ascidiacea } \\
\text { Ascidiacea (47) } \\
\text { Halocynthia papillosa (49) } \\
\text { Phallusia mammilata }(48)\end{array}$ & 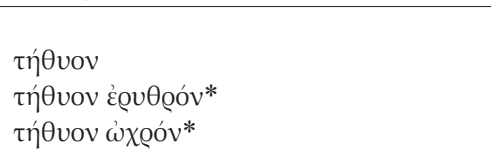 & $\begin{array}{l}\text { tēthyon } \\
\text { tēthyon erythron* } \\
\text { tēthyon ōchron* }\end{array}$ \\
\hline mes not cor & $\begin{array}{l}\text { sponding to current taxa } \\
\text { ropoda, Echinoidea, Asteroidea, } \\
7,38)\end{array}$ & 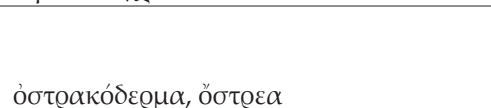 & ostrakoderma, ostrea \\
\hline
\end{tabular}

or economically interesting marine animals, e.g., octopus, sepia, lobster, crab, sea urchin. The names with more than 20 occurrences (Fig. 3) constitute over 50\% of total animal name records. Additionally, the number of records per animal group (times a group is mentioned) in the studied texts was compared with the number of current Aegean commercial species of the same benthic groups (as given by Chintiroglou et al., 2005b) (Fig. 4). Obviously, the pattern for all benthic groups was similar in both cases, indicating that the great philoso- pher focused his scientific interest on organisms exploited by humans in various ways (see also Fig. 4).

As previous studies have shown, the zoological information derived from the study of classical texts may help historical biogeographers in the reconstruction of the faunas of older epochs (Voultsiadou and Tatolas, 2005). Historical data on biodiversity are much appreciated by modern scientists, although they sometimes require that we sacrifice some of the precision and analytical elegance 


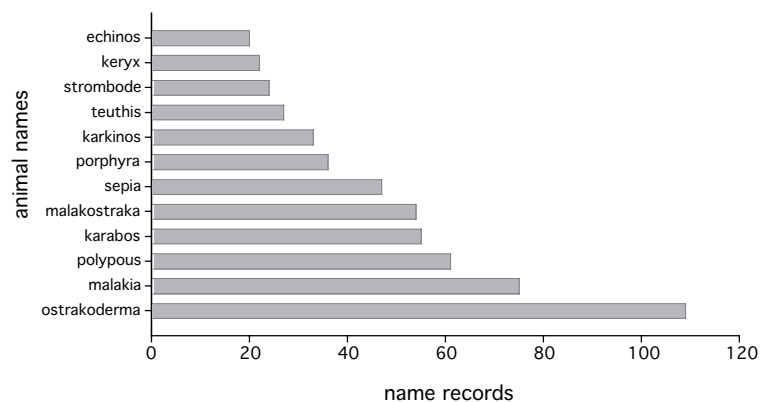

Fig. 3. Highly recorded (more than 20 occurrences) animal names in Aristotle's zoological works.

(Jackson et al., 2001). In an attempt to examine the general biodiversity pattern in the Aegean as illustrated in Aristotle's works, the only source of information for the status of marine fauna 25 centuries ago, and to evaluate his scientific knowledge of benthic diversity, a comparison of benthic taxa diversity given in his works with the relative current data for the Aegean Sea (as given by Chintiroglou et al., 2005a) was made (Fig. 4). The comparison showed that Aristotle had a remarkable, wellbalanced scientific knowledge of the diversity of the various invertebrate groups, very similar to the one acquired by modern marine biologists in the same area of study. Lennox (2001b) questioned the taxonomic purpose of the Aristotle's grouping of animals since "as one can see they differ widely in extension". However, on the

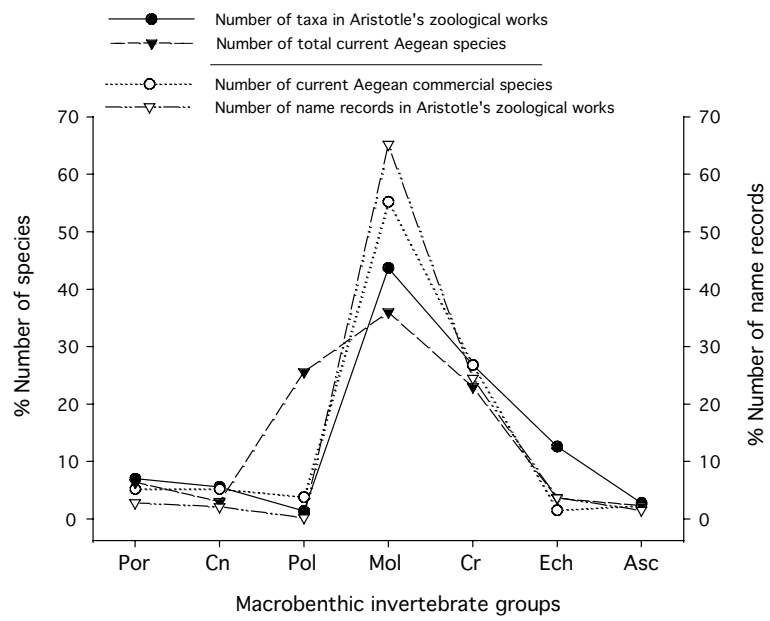

Fig. 4. Aristotle's knowledge of macrobenthic invertebrate diversity as compared to the current knowledge. Animal groups: Por, Porifera; Cn, Cnidaria; Pol, Polychaeta; Mol, Mollusca; Cr, Crustacea; Ech, Echinodermata; Asc, Ascidiacea. basis of the above comparison, the difference in the extension of Aristotle's groups should be attributed to the uneven distribution of species inside higher groups. The differences existing between the number of taxa recorded by Aristotle and the number of current taxa inside groups (Fig. 4) only means that Aristotle had given to molluscs or cnidarians more attention than justified by the number of species of these groups. On the contrary, he did not pay much attention to polychaetes possibly due to their not so obvious variety of form.

In conclusion, we can say that Aristotle's contribution to the knowledge of the diversity of benthic marine invertebrates is very high, taking into account the absence of any zoological background and the primitive facilities of his age. He had a balanced scientific knowledge of all the major benthic invertebrate groups. There have been difficulties with the recognition of various marine animals recorded in his writings by previous researchers, as shown by several wrong identifications. This study, conducted by Greek speaking marine zoologists living and diving in the same area with the great philosopher, thus being very familiar with the objects of his inquiry, contributed to the clarification of some confusing points. We think that it should be considered as a necessary starting point for any further analysis of the great philosopher's knowledge on the marine environment and its organisms.

\section{Acknowledgements}

We wish to thank A. Koukouras and C. Chintiroglou for helping with their experience in some difficult cases during the identification procedure and S. Gkelis for his valuable contribution, scientific and technical, in various stages of this work. We also appreciate the useful comments of Prof. F. Schram and an unknown reviewer, who improved our manuscript with their suggestions.

\section{References}

Balme DM. 1970. Aristotle and the beginnings of Zoology. Journal of the Society for the Bibliography of Natural History 5: 272-285.

Balme DM. 1991. Aristotle. History of Animals. Books VII-X. English translation, Introduction and Comments. Cambridge, Massachusetts: Harvard University Press.

Balme DM. (ed) 2002. Aristotle. Historia Animalium. Vol. I-X: Text. Cambridge: Cambridge University Press.

Brown RW. 1979. Composition of scientific words. A manual of methods and a lexicon of materials for the practice of logotechnics. Washington: Smithsonian Institution Press. 
Castro P, Huber ME. 1997. Marine Biology. Boston, Massachusetts: McGraw-Hill.

Chintiroglou C, Antoniadou C, Vafidis D, Koutsoubas D. 2005a. Zoobenthos - Hard substrata communities. In: Papathanassiou $\mathrm{E}, \mathrm{Zenetos} \mathrm{A}$, eds. State of the Hellenic marine environment, 247-253. Athens: Hellenic Center for Marine Research.

Chintiroglou C, Antoniadou C, Vafidis D, Koutsoubas D. 2005b. A review on the biodiversity of hard substrate invertebrate communities in the Aegean Sea. Mediterranen Marine Science 6: in press.

Delamotte M, Vardala-Theodorou E. 1994. Shells from the Greek Seas. Athens: Goulandri Natural History Museum.

Fischer W, Schneider M, Bauchot ML. 1987. Fiches FAO d'identification des espèces pour les besoins de la pêche. Mediterrannée et Mer Noire. Vol. I. Végétaux et Invertébrés. Rome: CEE, FAO.

Forster ES. 1961. Aristotle. Movement of Animals. Progression of Animals. English translation, Introduction and Comments. Cambridge, Massachusetts: Harvard University Press.

Gaston KJ, Spicer JI. 1998. Biodiversity. An Introduction. Oxford: Blackwell Science.

Gotthelf A, Lennox JG. (eds) 1987. Philosophical issues in Aristotle's biology. Cambridge: Cambridge University Press.

Gotthelf A. 1999. Darwin on Aristotle. Journal of the History of Biology 32: 3-30.

Hayward PJ, Ryland JS. (eds) 1990. The marine fauna of the British Isles and North-West Europe. Volumes I and II. Oxford: Clarendon Press.

Ingle RW. 1996. Shallow water crabs. Synopses of the British Fauna. London: The Linnean Society of London and the Estuarine and Coastal Sciences Association.

Jackson JBC, Kirby MX, Berger WH, Bjorndal KA, Borsford LW, Bourque BJ, Bradbury RH, Cooke R, Erlandson J, Estes JA, Hughes TP, Kidwell S, Lange CB, Lenihan HS, Pandolfi JM, Peterson CH, Steneck RS, Tegner MJ, Warner RR. 2001. Historical overfishing and the recent collapse of coastal ecosystems. Science 293: 629-638.

Kiortsis B. 1989. Aristotle, the founder of Biology - the science of Biology, its philosophy and perspectives. Thessaloniki: University Studio Press.

Koukouras A, Dounas C, Türkay M, Voultsiadou-Koukoura E. 1992. Decapod crustacean fauna of the Aegean Sea: new information, check list, affinities. Senckenbergiana maritima 22: $217-244$

Koukouras A, Voultsiadou-Koukoura E, Kevrekidis T, Vafidis D. 1995. Ascidian fauna of the Aegean Sea, with a check list of the Eastern Mediterranean and Black Sea species. Annales de l'Institut océanographique, Paris 71: 19-34.

Koutsoubas D, Koukouras A, Voultsiadou-Koukoura E. 1997. Prosobranch mollusc fauna of the Aegean Sea: new information, check list, distribution. Israel Journal of Zoology 43: 19-54.

Lee HDP. 1948. Place-names and the date of Aristotle's biological works. Classical Quarterly 42: 61-67.

Lennox JG. 2001a. Aristotle's Philosophy of Biology. Cambridge: Cambridge University Press.

Lennox JG. 2001b. Aristotle. On the parts of Animals I-IV. Translation, Introduction and Commentary. Oxford: Clarendon Press, 1-404.
Louis P. 1971. Animaux anonymes chez Aristote. Bulletin de l'Association Guillaume Budé 2: 211-217.

Louis P. 1973. Aristotle. Marche des animaux, Mouvement des Animaux, Index des traités biologiques. Paris: Belles Lettres.

Lloyd GER. 1961. The development of Aristotle's Theory of the Classification of Animals. Phronesis 6: 59-81.

Mayr E, Aschlock PD. 1991. Principles of Systematic Zoology. New York: McGraw-Hill.

Moore JR. 1987. Science as a way of knowing. IV. Developmental Biology. American Zoologist 27: 415-573.

Peck AL. 1942. Aristotle. Generation of Animals. English translation, Introduction and Comments. Cambridge, Massachusetts: Harvard University Press.

Peck AL. 1961. Aristotle. Parts of Animals. English translation, Introduction and Comments. Cambridge, Massachusetts: Harvard University Press.

Peck AL. 1965. Aristotle. History of Animals. Books I-III. English translation, Introduction and Comments. Cambridge, Massachusetts: Harvard University Press.

Peck AL. 1970. Aristotle. History of Animals. Books IV-VI. English translation, Introduction and Comments. Cambridge, Massachusetts: Harvard University Press.

Pellegrin P. 1982. Aristotle's classification of animals. Biology and the conceptual unity of the Aristotelian Corpus. English translation by A. Preus. Berkley: University of California Press.

Riedl R. 1963. Fauna und Frora der Adria. Hamburg: Verlag Paul Parey.

Ruppert EE, Fox RS, Barnes RD. 2004. Invertebrate Zoology. A functional, evolutionary approach. Belmont, California: Brooks/Cole-Thomson Learning.

Scharfenberg LN. 2001. Die Cephalopoden des Aristoteles im lichte der modernen Biologie. Trier: WVT Wissenschaftlicher Verlag.

Sofianidou T. 2004. Aristotle's contribution to modern Biology. Proceedings of the Sixth Panhellenic Symposium of the Historical and Folklore Society of Chalkidiki, Ierissos, October 2001: 309-319 (in Greek with English summary).

Solmsen F. 1978. The fishes of Lesbos and their alleged significance for the development of Aristotle. Hermes 106: 467-484.

Thompson D'Arcy W. 1913. On Aristotle as a biologist. Oxford: Clarendon Press.

Thompson D'Arcy W. 1947. A glossary of Greek fishes. London: Oxford University Press.

Thompson D'Arcy W. 1966. A glossary of Greek birds. Hildesheim: Georg Olms Verlagsbuchhandlung.

Tipton JA. 2006. Aristotle's study of the animal world. The case of the kobios and phucis. Perspectives on Biology and Medicine 49: 369-383.

Vafidis D, Koukouras A, Voultsiadou-Koukoura E. 1994. Octocoral fauna of the Aegean Sea with a check list of the Mediterranean species: new information, faunal comparisons. Annales de l'Institut océanographique, 70: 217-229.

Vafidis D, Koukouras A, Voultsiadou-Koukoura E. 1997. Actiniaria, Corallimorpharia and Scleractinia (Hexacorallia, Anthozoa) of the Aegean Sea, with a check list of the Eastern Mediterranean and Black Sea species. Israel Journal of Zoology 43: 55-70. 
Voultsiadou E, Tatotas A. 2005. The fauna of Greece and adjacent areas in the Age of Homer: evidence from the first written documents of Greek literature. Journal of Biogeography 32: 1875-1882.

Voultsiadou E. 2005. Sponge diversity in the Aegean Sea: check list and new information. Italian Journal of Zoology 72: 53-64.

Voultsiadou-Koukoura E, Koukouras A, Eleftheriou A. 1987. Macrofauna associated with the sponge Verongia aerophoba in the North Aegean Sea. Estuarine coastal and Shelf Science 24: 265-278.

Weinberg S. 1993. Découvrir la Méditerranée. Paris: Éditions Nathan.

Received: 6 November 2006

Accepted: 6 March 2007 